\title{
Euskararen i(ra)kaskuntza-prozesuak: hezkuntza eta hizkuntza teknologiak
}

\author{
Educational processes of the Basque language: \\ educational technology and language technology \\ Abel Camacho $^{1}$, Mikel Iruskieta ${ }^{2 *}$ \\ ${ }^{1}$ Udako Euskal Unibertsitatea (UEU) \\ ${ }^{2}$ Hizkuntzaren eta Literaturaren didaktika saila, UPV/EHU Leioa
}

LABURPENA: Ingurune digitalean bizi arren, bi arazo ezberdin izan ditzakegu: bat, teknologiaren eraldaketa azkarra edota egokitu gabekoa izatea eta, bi, euskara eta antzeko baliabide mugatuetako hizkuntzetan behar diren teknologiak ez sortzea edota erabilgarri ez egotea.

Artikulu honetan, euskara ikasteko, irakasteko eta ikertzeko prozesuetan teknologiak testuinguru multimodal eta aberats honetan zer-nolako ekarpenak egin ditzakeen aztertu nahi dugu. Horretarako, teknologia-motak kontuan hartuta, ikasleek nahiz irakasleek dituzten erronkak eta aukerak deskribatzen saiatuko gara, horiei erantzuteko hainbat aplikazioren azalpen eta adibide emanez. Horrez gain, erronka horietan ditugun gabeziei erantzuteko, norberak, komunitateak eta hizkuntzaren garapenerako azpiegiturek helduen euskararen irakaskuntzan izan dezakeen garrantzia nabarmenduko dugu.

GAKO-HITZAK: euskara, hezkuntza-teknologia, hizkuntza-teknologia, irakaskuntza-prozesua, ikaskuntza-prozesua, helduen euskalduntzea.

ABSTRACT: Although digital technology is present in our life, we can suffer two different problems coming from opposite poles: the rapid or inadequate transformation of technology in language teaching and the scarce development of language technologies in under-resources languages communities like Basque.

In this article, we want to explore how technology can contribute to the learning, teaching and research processes of Basque in a multimodal teaching approach. To this end, we describe those challenges that students and teachers have from the technological point of view, explaining and giving examples of technology that can help in the learning process of Basque language. Furthermore, we stress the importance of addressing personal deficiencies, as well as deficiencies of the learning community and infrastructures that works for the development of language technology in the teaching of Basque for adults.

KEYWORDS: basque, educational technology, language technology, teaching processes, learning processes, acquisition of Basque language for adults.

* Harremanetan jartzeko / Corresponding author: Mikel Iruskieta. UPV/EHU. HiTZ zentrua. Hizkuntzaren eta Literaturaren Didaktika Saila. Sarriena auzoa z/g. 01006 Leioa. Bizkaia. - mikel.iruskieta@ehu.eus - https://orcid.org/0000-0002-6121-3902

Nola aipatu / How to cite: Camacho, Abel; Iruskieta, Mikel (2020). «Euskararen i(ra)kaskuntza-prozesuak: hezkuntza eta hizkuntza teknologiak». Tantak, 32(2), 9-31. (https://doi.org/10.1387/tantak.21654).

Jasotze-data: 2020/04/16; Onartze-data: 2020/05/13

ISSN 0214-9753 - elSSN 2444-3581 / (c) 2020 UPV/EHU

(c) (i) Obra hau Creative Commons Atribución 4.0 Internacional-en lizentziapean dago 


\section{SARRERA}

Kontu jakina da oso urte gutxitan jendartearen ohiturak zeharo aldatu direla teknologiaren etengabeko garapenari esker. Horrela, ingurune digitalean bete-betean bizi gara eta geure egunerokoan ohikoak ziren hainbat eta hainbat ekintza bestela burutzen ditugu egun: paperezko hedabideen ordez, gero eta maizago erabiltzen ditugu digitalak; banketxeetara joan beharrean, gero eta online eragiketa gehiago burutzen ditugu; salerosketak ere gero eta gehiagotan gertatzen dira birtualitatean. Egun, COVID-19ak sortutako osasun krisia dela eta, inoiz baino behar handiagoa agertu da online irakaskuntza metodologiek eta teknologia-motek eskaintzen dituzten abantailak erabiltzeko eta zenbait oztopok edo garapen faltak ekar dezakeen arriskuak ezagutzeko.

Aurrekoarekin bat, ukaezina da datu-multzo edo corpus handien garaian bizi garela. Lopez de Lacallek (2019) dioen moduan, «datuetan oinarritutako erabakiak hartzen dira gaur egun gizarteko alor guztietan. Bai finantza-munduan, bai medikuntzan, bai hizkuntzalaritzan, datuetatik abiatzen gara ezagutza lortzeko, fintzeko eta erabaki hobeak hartzeko». Gainera, erregistroak anitzak izateaz gain, datu-tipologia ere zabaldu egin da, datu multimodalak eta testuinguru aberatseko eta hurbileko ebidentziak gure esku ditugula. Gainera, datuak konputagarriak eta estekatuak dira, horien bisualizazioa eta erabilera errazteko.

Hezkuntzan ere, aldaketa teknologiko horiek guztiek eragin handia dute, eta uste izatekoa da datozen urteotan gero eta handiagoa izango dutela. Helduen euskalduntzea ez da joera orokor horretatik aparte geratzen eta gaur egun oso ohikoak bihurtu zaizkigu era guztietako tresnak eta aplikazioak euskara ikasi eta irakasteko prozesuetan.

Jarraian, helduen euskalduntzean teknologiek zer-nolako ekarpenak egin ditzaketen aztertzen saiatuko gara zenbait adibide emanez. ${ }^{1}$ Hori egin aurretik, lehenik eta behin testuinguruko hainbat alderdi argitu nahi ditugu. Gero, hezkuntza- eta hizkuntza-teknologien erabilerarako gutxieneko baldintzak zirriborratu eta hainbat adibide eta tresna zerrendatuko ditugu. Amaitzeko, arazo, erronka eta aukera nagusiak zirriborratuko ditugu.

\section{TESTUINGURUA}

\subsection{Euskararen didaktika}

Euskaltegietako euskararen didaktikaz ari zela, Peralesek (2000) dio 1980tik 2000ra bitarteko tartean jorratutako irakaskuntza-moldea bi oinarri

\footnotetext{
1 Adibide horien garapena, ariketak egiteko datuak, jarraibideak eta hemen aipatu ez ditugun bestelako baliabide interesgarriak honako webgunean jarriko ditugu: https://hezikt. eus/teknologiak/.
} 
nagusitan ardazten zela: a) gramatika-egiturei jarraitzen dien aurrerabidea, eta b) hizkuntzaren ahozko erabilerari eskainitako arreta berezia. Orduan indarrean zeuden programa ofizialek (HABE, 1983; 1989) ikuspegi formal hori balioesten zuten.

Garai berean, Alfabetatze Euskalduntze Koordinakundea (AEK) ari zen Wilkinsen (1976) ekarpenak euskalduntze-prozesura egokitu nahian, eta horretarako egindako proposamen metodologikoan ikasleen komunikazio-beharrak nozioen eta funtzioen bidez definitu ziren (AEK, 1989), euskara ikasi eta irakasteko prozesuen erdigunean lehenbiziko hurbilpen komunikatibo arrazoitua jarriz. ${ }^{2}$

Gerora, dakigunez, Euskal Herrian hainbat curriculum-diseinu onartu eta bultzatu dira, orduko ikuspegi formalak gainditze aldera:

- Euskal Autonomia Erkidegoan curriculum-berrikuntzarako bi egitasmo bultzatu ditu Helduen Alfabetatze eta Berreuskalduntzerako Erakundeak (HABE). Lehena 1999an, Helduen Euskalduntzearen Oinarrizko Kurrikulua (HEOK), eta bigarrena 2015ean, Helduen Euskalduntzearen Oinarrizko Curriculuma, (HEOC).

- Nafarroako Gobernuak 2011ko ekainaren 24an argitaratu zuen Helduak Euskalduntzeko Nafarroako Curriculuma (HENAC), ordutik indarrean dagoena.

Aipaturiko azken bi curriculum-diseinuen oinarri-oinarrian Europako Kontseiluak 2001ean argitara emandako Hizkuntzen Erreferentzia Marko Bateratuaren ekarpenak daude, non funtsezko hainbat elementu azaltzen diren, besteak beste, hizkuntza-ikaslea eta hizkuntza-erabiltzailea bat bera izatea; gaitasunak eta azpigaitasunak funtsezkotzat jotzea, edo erreferentzia-mailak eta horien definiziorako adierazle argigarrien eskalak ikasteko eta irakasteko prozesuen gidari izatea. Horrekin batera, ikasten ikasteak berebiziko garrantzia hartuko zuen, baita ikaskuntza egoera eta eginkizun komunikatiboetan ardazteak ere.

Dakigunez, Europako Kontseiluak 2018an Erreferentzia Markoaren liburuki osagarria eman du argitara eta, besteak beste, ${ }^{3}$ online interakzioa deskribatzeko eskala argigarriak diseinatu ditu, elkarrizketa eta lankidetza ardatz hartuta.

2 Jokabide nozio-funtzionalean komunikazioa helburu bazen ere, Breenek (1987) proposiziozko programen barruan kokatu zituen programa funtzionalak, era formalean azaltzen baitute ikaskuntza eta irakaskuntzaren bidez zer lortu behar den.

${ }^{3}$ Liburukian hizkuntza ikasi eta irakasteko kontzeptu gakoak azaltzen dira sarrera gisa, eta gero deskribatzaile-multzo berrien diseinua aurkezten da, 2001eko bertsioan hutsuneak zituzten zenbait eskala berridatziz eta, batez ere, hiru alderdi bereziki kontuan hartuz: a) bitartekaritza; b) gaitasun eleanitza eta kultur-aniztasuna, eta c) online interakzioa. 
Aldagai didaktikoak gorabehera, ez dirudi Helduen Euskalduntzean indarrean dauden curriculumak ingurune digitalean bizi den jendartearekin lotzen direnik, ezta teknologiak euskara ikasteko eta irakasteko prozesuei egin diezaiekeen ekarpenaz inongo hausnarketarik jasotzen dutenik ere. ${ }^{4}$

\subsection{Teknologiak eta hizkuntzen ikaskuntza eta irakaskuntza}

Hizkuntza-irakaskuntzaren eta teknologiaren arteko harremana luzea bezain emankorra izan da (Trujillo, Salvadores eta Gabarrón, 2019). Are gehiago, teorikoki hizkuntzak irakasteko hurbilpen edota metodologia bakoitzak bere teknologia propioak izan ditu, horietan oinarritu eta sostengatzeko (Warschauer eta Meskill, 2000). ${ }^{5}$ Hizkuntza-metodoen historian, beraz, ez dira batere berriak teknologiekiko kezka eta ardura. Gaur egungo egoerarekin alderatuta, ordea, azpimarratzekoa da era eta molde guztietako teknologien garapen azkarra eta etengabea.

Horrela, kontrakoa iruditu dezakeen arren, oso urte gutxi pasatu dira lehenbiziko ahozko testu-grabazio haietatik (kaseteak nahiz CD-ROMak izan) ikasleek ingurune digitalean eskura dituzten baliabide eta aukeretara. Bi denbora-muga horien artean hainbat teknologia ezagutu ditugu, besteak beste, Ordenagailuak Lagunduriko Hizkuntza Ikaskuntza (CALL), edo geroago Interneten zabalkundeak ekarri zituen tresnak (nabigatzaileak, posta elektronikoa eta webguneak), edo Interneten alderdi soziala indartzetik sortu zen Web 2.0 izenekoarenak (sare sozialak eta blogak), edo gailu mugikorrak (tabletak eta telefonoak), edo big data eta corpus handiak erabilita sortu diren hiztegiak, ikerketak, curriculumak, analitikak eta metrikak.

Euskal Herrira bagatoz, une honetan ez dago azterlanik, datuetan oinarrituta behintzat, teknologiak euskaltegietako hezkuntza-jardunean zein rol jokatzen duen ikertu duenik, ezta zein den teknologiaren erabileraren intentsitatea ere. Hala ere, jakin badakigu era askotako esperientziak eta erabilerak izan direla azken urteotan.

Euskara ikasteko online materialei dagokienez, autoikaskuntzarako testuinguruetan hipertestua sortu ahal izateko materialgintza-proiektua abiatu zen (Camacho, 2004). Geroago, HABEk (Dorronsoro, 2014) www.ikasbil.net

${ }^{4}$ Bereziki harritzekoa da, 2015eko testua izanik, HEOC zeharo zaharkitua jaio izana, ikuspuntu digitaletik aztertuta bederen.

5 Nabarmendu nahi dugu Warschauerrek eta Meskillek (2000) esandakoari hizkuntza bakoitzak ere bere baliabideak eta teknologia behar dituela. Izan ere, morfologia sinplea duten hizkuntzentzat sorturiko baliabideek ez dute baliagarritasun bera morfologia aberatsa dutenekin konparatuz. Bestalde, hizkuntzatik hizkuntzara arau eta erabilera ezberdinak garrantzitsuak izaten dira. 
ataria sortu zuen, euskara ikasten eta irakasten ari diren herritarrei zerbitzu didaktikoak emateko asmoz. Ordutik, mota eta molde askotako ikas-materialak argitara ematen dira (Lopetegi, 2015a; Lopetegi, 2015b).

Ikas-materialen online biltegi horiez gain, e-learning eta b-learning testuinguruetan euskaltegien munduan euskara ikasteko esperientzia aberatsak bultzatu dira (Camacho, 2019; Tolosa, 2019), eta Moodle izeneko LMSak oso erabilera zabala lortu du gure artean (Camacho eta Lonbide, 2016). Horrela, Moodleren tresnen erabilera didaktikoak landu eta proposatzeko lanen artean, aipatzekoak dira Lasherasek (2010) wikia gelan erabiltzeko egindako proposamenak, baita glosategia erabiltzekoak ere (Lasheras, 2011). Halaber, Urainek (2010) b-learning moldeko talde mistoetan Moodleren foroak erabiltzeko zenbait iradokizun egiten ditu.

Aurrekoez gain, euskara ikasteko blogak (Saenz de Biteri, 2009), WhatsApp (Aldazabal et al., 2015) edo Instagram (Arteach, 2016) eta antzeko sare sozialek eskain ditzaketen onurak baliatzeko esperientziak izan dira; bideokonferentzia bidez eskaintzen dira euskara ikasteko saioak (Iturricastillo, 2015). Gizatalde askotarikoen beharrei egokitutako eskaintza akademikoaren alorrean, HABEk Euskal Herrira heldutako etorkinak euskarara hurbiltzeko helburua duen online ikastaroa sortu du (Zubizarreta, 2013).

Ebaluazioaz ari bagara, une honetan, euskararen ezagutza-mailen ordenagailu bidezko egiaztatzegintza ere lantzen ari da, nazioartean erabiltzen diren eredu eta irizpideetara biltzeko bidea egin nahian. Horren xedea da paper bidezko egungo egiaztatzegintza-eredu trinkoa gainditzea eta gaur egungo ingurune informatizatura egokitutako sistema malgu bat ezartzea (Sagarzazu, 2019).

Euskaltegietako irakasleen konpetentzia digitalari dagokionez, Guillének eta Aizpitartek (2015) nortasun digitalaren gaia aztertu dute; gaitasun profesionala areagotzea helburu duten ikas-komunitate edo ziberkomunitateak sortu eta bultzatu dira (Murua eta Txabarri, 2016), eta euskaltegietako irakasleen gaitasun digitalaren garapen-maila aztertuta, egiaztatu da emaitzak baxuagoak direla EAEko Hezkuntza-sistema formalean lanean ari diren irakasleena baino (Murua, 2016).

Hala ere, euskaltegietako profesionalek aztertu beharra dute hezkuntzanahiz hizkuntza-teknologiek zer-nolako ekarpenak egin ditzaketen euskalduntze-prozesuan, bai eta eguneroko jardunean zer-nola erabili behar diren ere. Jarraian, bi teknologia-mota horien aplikaziorako testuingurua aztertuko dugu, bai eta zenbait tresna ere.

\section{HEZKUNTZA-TEKNOLOGIAK}

Azken boladan auzian jarri da ikasteko eta irakasteko helburuz erabiltzen diren teknologiei nola deitu behar ote zaien. Roman-Mendozak (2018) 
dioenaren ildotik, oraintsura arte ohikoa izan den Informaziorako eta Komunikaziorako Teknologiak (IKTak) terminoak teknologiaren ikuspegi instrumentala adierazten du, hau da, teknologiaren erabilgarritasuna neurtzen du bakar-bakarrik trebetasun jakin bat bultzatzeko balio duen neurrian. Hori ekidite aldera, Parte Hartzearen eta Ahalduntzearen Teknologiak (PHATak) terminoa proposatu bada ere, Ikaskuntzaren eta Ezagutzaren Teknologiak (IETak) izenekoak hoberen adieraz dezake gaur egun dagoen beharra datuetan oinarritutako hezkuntzan.

Horrela, era guztietako tresna digitalak, aplikazioak edo baliabideak ditugu eskura gaur egun. Horietako asko aplikazio bakarrean bildurik agertzen zaizkigu, ikasgela birtuala edo Learning Management System (LMS) delakoa osatuz. Horietan, hainbat erabiltzaile-mota izaten dira (kudeatzaileak, irakasleak eta ikasleak) eta hainbat prozesu (kudeaketa, ikaskuntza eta ebaluazioa) burutzeko tresnak ditugu eskura. Gure artean, Moodle da ezagunena, baina badira beste hainbat LMS ere zabalkunde handikoak, hala nola Blackboard, Canvas, Edmodo edo Google Classroom.

Helduen Euskalduntzean oso ohikoa da Moodleren erabilera eta horrela, hainbat dira Moodle instalazio propioa duten euskaltegiak edota euskaltegi-sareak. HABEk ere euskaltegien esku uzten du Moodle instantzia, euskaltegiei kudeaketa eta bestelako kontu teknikoetatik libratuz. Edonola ere, ikasgela birtualen erabilera handiak ez dakar, derrigorrean, benetako berrikuntza metodologikorik, eta ez dago zalantzarik zer hobetu asko dugula alderdi horretan (Camacho eta Lonbide, 2016).

LMSetatik at dauden tresnei dagokienez, Arroyo-Sagastak eta Pereirak (2019) diote «sarean edozer egiteko aukera eskaintzen dituzten milaka aplikazio daudela. Guztiak ezagutzea ezinezkoa da, etengabe desagertu, berritu eta agertzen direlako; baina tresna digital horiek sailkatzeak gidalerro batzuk eskain diezazkiguke, baita ondo erabiltzen lagundu ere: «Zertarako?' galdera buruan izanda, tresna digital egokia aukeratzeko gakoak izan ditzakegu».

Hona hemen, beraz, Arroyo-Sagastak eta Pereirak (2019) aipatutako lanean tresna digitalen sailkapena egiteko egindako proposamena: 


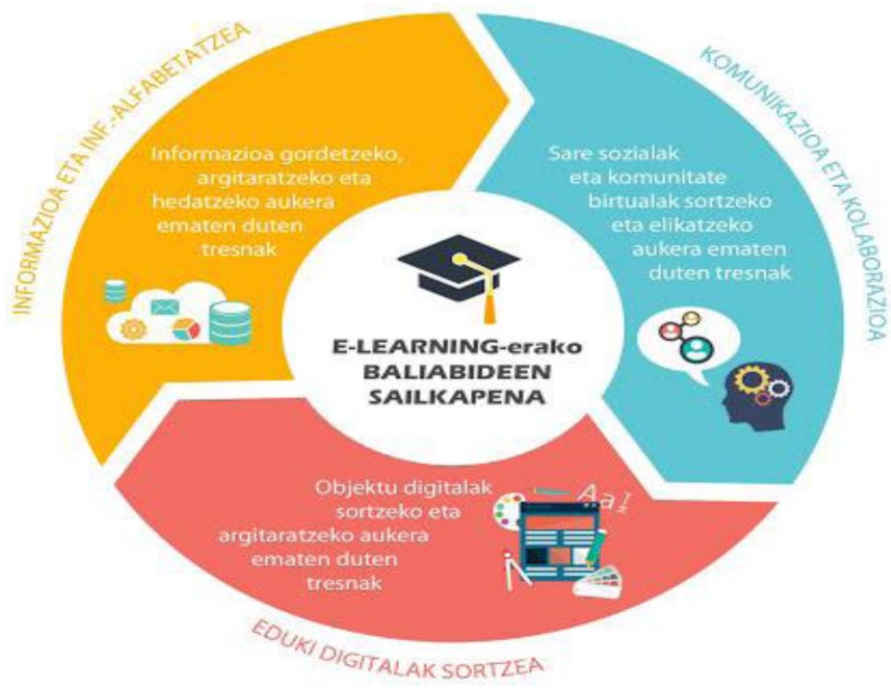

Iturria: Arroyo-Sagasta eta Pereira (2019).

1. irudia

E-learningerako baliabideen sailkapena

Sailkapenak bi oinarri ditu: a) Konpetentzia digitala: DIGCOMP markoak zehazten dituen bost arloetatik, hiru aukeratu dituzte sailkapenaren oinarritzat (informazioa eta informazio-alfabetatzea, komunikazioa eta kolaborazioa, eta eduki digitalak sortzea), eta b) Erabilera pedagogikoa: arlo bakoitzaren barruan, ikas-prozesuetarako erabilgarritasuna azpimarratuko duen «zertarako?» galderari erantzunez, lehenago aipatu dugun instrumentalismo teknologikoa gainditu nahian. ditu:

Tresnei dagokienez, Arroyo-Sagastak (2019) ondokoak azpimarratu

- Informazioa gordetzeko, argitaratzeko eta hedatzeko tresnak:

- Google Drive: dokumentuak gordetzeko, editatzeko eta partekatzeko tresna.

- Diigo: laster-markak gordetzeko tresna.

- Feedly: RSSak edo jarioak irakurtzeko tresna.

- Sare sozialak eta komunitate birtualak sortzeko eta elikatzeko tresnak:

- Twitter: komunikazio horizontalerako tresna.

- Blogger: bloga sortzeko tresna.

- Skype: bideo-deiak egiteko tresna. 
- Objektu digitalak sortzeko tresnak:

- Genially: aurkezpen interaktiboak sortzeko tresna.

- Educaplay: jolasak sortzeko tresna.

- Adobe Spark: bideo-edizio errazak egiteko tresna.

Ildo beretik, Roman-Mendozak Catálogo de TAC y buenas prácticas izeneko webgunean (https://labur.eus/KSeRi) tresna teknologikoak eta praktika onak jasotzen dituen datu-basea atondu du. Hor bilaketak egiteko hainbat modu eskaintzen dira, baina azpimarratzekoak dira: a) funtzio instrumentalen arabera egin daitezke bilaketak (adibidez, URLa laburtu, argazkiak partekatu eta denbora-lerroak sortzea), eta b) ekintza didaktikoen bidez (bildu, partekatu, sortu eta antolatzea).

\section{HIZKUNTZA-TEKNOLOGIAK}

Test moduko ohiko ariketez gain, ikasleari feedback automatiko esanguratsua eman nahi badiogu, ikasleak idazten duen informazioa momentuan ulertu behar du aplikazioak edo ordenagailuak. Izan ere, ezin dugu aldez aurretik jakin ikasleek zer idatziko duten. ${ }^{6}$ Hori horrela, ikasleak idatziko duena momentuan aztertu behar da, nolabaiteko feedbacka unean bertan eman nahi bazaio. Horretarako, hizkuntza prozesatu beharra dugu. ${ }^{7}$

Hizkuntza-teknologiaz ari gara sistema informatikoetan giza hizkuntzari buruzko jakintza aplikatzen dugunean, hizkuntza (bere forma guztietan) ezagutzeko, ulertzeko, interpretatzeko eta sortzeko. Hizkuntzaren deskribapena oso ataza zaila izan arren, hizkuntza-teknologiak aurrerapen handia ezagutu du hasierako hurbilpen teoriko eta erregela sistemetatik hasi (1980-1995 urte bitartean), ondorengo hurbilpen enpirista eta ikasketa automatikoaren garapenera arte (1995-2005 urte bitartean) eta azken garai honetan sare neuronalen bidezko ikasketa automatikoan oinarritutako sistemetara.

${ }^{6}$ Berdin gertatzen da irakurgaiekin: egun ikasleen zaletasunak oso ezberdinak izan daitezke eta oso testu ezberdinak irakurtzea aukeratu dezakete. Gauza bera, ahozko jardunarekin. Zein zaila den talde bateko ikasle guztien interesekoa izan daitekeen mintzagaia aukeratzea.

${ }^{7}$ Hizkuntzaren prozesamendua egiten da ordenagailuak testuak irakurri, testuko hitzak kontatu, elementuak konparatu eta testuetatik informazioa erauzi ahal izateko. Horretarako, testuak prozesatu egiten dira, hau da, testuko hitzak ezagutzen dira edota testutik bereizten dira eta, ondoren, hitzak errepresentatu edo informazio linguistikoa gehitzen zaie. Hau da, informazio hori esplizitu egiten da ordenagailuak etiketa horiek ezagutzeko edota beste prozesu batzuetan etiketa horiek beste batzuez ordezkatzeko. Ordenagailuari «X badago» orduan «Y egin» bezalako erregelekin hizkuntzaren egitura ezberdinak deskribatzen zaizkio. Eta modu honetan, errepikatzen diren atazak azkar egiten dituzte ordenagailuek. Prozedura horri jarraituz, ikerkuntzarako hainbat ataza interesgarri egin izan dira. Hizkuntzaren prozesamenduari buruz gehiago jakiteko jo Aldezabal et al.en (2005) eta Hernáez et al.en (2012) lanetara.

Ataza nabarienak eta horien egoera jakiteko jo webgune honetara: http://nlpprogress.com. 
Garai honetan digitalizazioak dakartzan aukera berriei erantzuteko, CLARIN hizkuntza-teknologia garatzeko ikerketa-azpiegitura europarra sortu da (Hinrichs eta Krauwer, 2014) eta partaide diren herrialdeetan azpiegitura egokiak garatu dituzte. Nabarmena da Herbeheretan nola garatu dituzten hizkuntza-teknologiak CLARIAH azpiegituran. Euskarazko hizkuntza-teknologiak garatzeko ikerketa-azpiegitura europarrik ez dago, baina CLARINen partaide ofizial gisa sartzeko helburuarekin sortu da CLARIN-K (Bel et al., 2016) eta bertan euskaraz gain, galiziera, katalana, gaztelania eta antzeko hizkuntza-teknologia garatzeko helburua da nagusi.

Beraz, oraingoz, euskararako horrelako ikerketa-azpiegiturarik ez badago ere, hainbat ikerketa-talde teknologia sortzen ari dira (Euskaltzaindia, Ixa Taldea, Euskara Institutua, Elhuyar, Aholab, UZEI, besteak beste). ${ }^{8}$ Horien lanari esker, jendartean eta eskoletan arrakasta lortu duten zenbait teknologia erabiltzen dira. Esaterako, aipagarriak eta arrakastatsuak dira, Euskalbar, Xuxen, Hobelex eta TTS Aholab pluginak, Aditu ahotsa transkribatzeko sistema, corpusak, corpusak aztertzeko tresnak (ANALHITZA) edo bestelako online zerbitzuak, ikasleek ezer instalatu gabe eta jakintza teknikorik gabe ondo erabil ditzaketelako. Bestelako hizkuntza-teknologiari buruzko katalogoak-eta egon badauden arren, ${ }^{9}$ tresna horiek erakunde bakoitzaren webguneetan daude eta erabiltzaileek ez dute jakiten zer dagoen eta non dagoen. CLARIN-EUS eta antzeko hizkuntza-azpiegiturak horiek denak bildu eta mantenduko lituzke.

Hizkuntza-teknologia baliagarria da ariketa analitikoak egiten direnean laguntzeko, esaterako, eskolan askotan errepikatzen diren eginkizunak egiteko, irakasleari denbora aurreztuz eta, horrez gain, modu analitikoan egiten denari balio erantsia emateko ere balio du, eta ikasle bakoitzaren garapena neurtu edota ikasle-multzoen ahozko eta idatzizko produkzioaren analisia egiteko. Horiek kudeatzeko, hezkuntza-teknologiaz (LMSak) baliatu beharko dugu, baina gero ikasleak esandakoa edota idatzitakoa aztertu nahi badugu, hizkuntza-teknologiaz baliatu behar dugu. Nazioartean hezkuntza- eta hizkuntza-teknologiak modu egokian garatzen dituzten inguruneak ere sortu dira eta ikerketa-fasean badaude ere, aurrerapen garrantzitsuak egiten ari dira (Rudzewitz et al., 2019).

Horiek horrela, euskara ikasteko baliagarri izan daitezkeen zenbait baliabide teknologiko aipatuko ditugu 1. taulan. Baliabideak eta tresnak motaren arabera (hizkuntza-teknologia eta hizkuntza i(ra)kasteko baliabideak) sailkatu ditugu, eta gero horiek betetzen duten egitekoaren eta ingurunearen arabera (trebetasunak, hizkuntzaren analisia, eta erabilera-ingurunea).

\footnotetext{
${ }^{8}$ Ixa taldeko baliabide-zerrenda: http://ixa.si.ehu.es/produktuak?language=eu.

9 Aipagarria da Xabier Alberdiren hizkuntza-baliabideen zerrenda hau: https://sites.google.com/site/euskarateknikoakazetaritza/et1_1hizkuntza-baliabideak.
} 


\section{1. taula}

Hizkuntza-teknologia, baliabide digitalak eta hizkuntza-trebetasunak (ikusi webgrafian tresna horien URLak)

\begin{tabular}{|c|c|c|c|}
\hline & & Hizkuntza-teknologia & Hizkuntza i(ra)kasteko baliabideak \\
\hline \multirow[t]{4}{*}{ Trebetasunak } & Mintzamena & $\begin{array}{l}\text { PRAAT eta WaveSurfer: } \\
\text { fonetika aztertzeko }\end{array}$ & $\begin{array}{l}\text { - } \begin{array}{l}\text { Mintzanet: mintzapraktikak } \\
\text { grabEx: mintzapraktikak } \\
\text { backa eman }\end{array} \\
\text { batarekin feed- } \\
\end{array}$ \\
\hline & Entzumena & $\begin{array}{l}\text { - } \begin{array}{l}\text { Ahotts: testua ahots } \\
\text { bihurtzeko } \\
\text { Aditu.eus: bideo edo au- } \\
\text { dio fitxategietan esaten } \\
\text { dena testu bihurtzeko }\end{array} \\
\end{array}$ & $\begin{array}{l}\text { Ahotsak.eus: bariazioa, } \\
\text { baina baita eredugarria ere } \\
\text { Ikuslang: ahozko testua eta } \\
\text { komunikazio-estrategiak lan- } \\
\text { tzeko }\end{array}$ \\
\hline & Idazmena & $\begin{array}{l}\text { - IDAZLAGUN: idazteko } \\
\text { eta zalantzak argitzeko } \\
\text { ingurunea } \\
\text { - AhoSR: ahotsa testu } \\
\text { bihurtzeko } \\
\text { - Xuxen, Hobelex: zuzen- } \\
\text { tzaileak } \\
\text { - ANALHITZA, Voyant: } \\
\text { aztertzaile morfo-lexika- } \\
\text { lak } \\
\text { - Lexikoaren Behatokia: } \\
\text { corpusa zalantzak kon- } \\
\text { tsultatzeko }\end{array}$ & $\begin{array}{l}\text { MARKIN tool, wikiak; } \\
\text { Drive, zuzenketa ingurunean } \\
\text { Hot Potatoes: ariketa auto- } \\
\text { matikoak } \\
\text { - Grammarly: testuen zuzen- } \\
\text { keta automatikoa }\end{array}$ \\
\hline & Irakurmena & $\begin{array}{ll}\text { - } & \text { ElhuyarTTS testua ahots } \\
\text { bihurtzeko } \\
\text { - } & \text { Testu Historikoak }\end{array}$ & $\begin{array}{ll}\text { - } & \text { HIZEBA: test egokitua } \\
\text { - } & \text { Armiarma, e-liburutegia: li- } \\
& \text { buruak, audio-testuak... }\end{array}$ \\
\hline $\begin{array}{l}\text { Hizkuntzaren } \\
\text { analisia }\end{array}$ & $\begin{array}{l}\text { Hizkuntzaren } \\
\text { alderdi } \\
\text { formalak } \\
\text { aztertzeko } \\
\text { aplikazioak }\end{array}$ & $\begin{array}{ll}\text { - } & \text { EDBL: datu-base lexikala } \\
\text { - } & \text { Morfeus: analizatzaile } \\
\text { - } & \text { MALTIXA: analizatzaile } \\
\text { sintaktikoa } \\
\text { - } \\
\text { Modela: Itzulpen automa- } \\
\text { tikoa } \\
\text { - Lextutor: baliabideak sor- } \\
\text { tzeko, ikuspegi lexikale- } \\
\text { tik }\end{array}$ & $\begin{array}{ll}\text { - } & \text { Corpusak } \\
\text { - } & \text { Euskalbar, Euskalterm, hiz- } \\
\text { tegiak.net } \\
\text { - } \\
\text { EHULKU, SEG, Euskal- } \\
\text { tzaindia: Gramatika lante- } \\
\text { giak } \\
\text { - UD corpusa eta Arborator: } \\
\text { euskarazko zuhaitz sintakti- } \\
\text { koak manipulatzeko }\end{array}$ \\
\hline Inguruneak & $\begin{array}{l}\text { Eskolan } \\
\text { erabiltzeko } \\
\text { inguruneak }\end{array}$ & $\begin{array}{l}\text { Compress-Eus: laburpe- } \\
\text { nak kudeatzeko eta eba- } \\
\text { luatzeko tresna } \\
\text { - SENEKO: galdera-eran- } \\
\text { tzun sistemak garatzeko } \\
\text { ingurunea }\end{array}$ & $\begin{array}{ll}\text { - } & \text { Ikasbil } \\
\text { - } & \text { Euskaljakintza } \\
\text { - } & \text { Santurtziko Udal Euskaltegia } \\
\text { AEKo egela }\end{array}$ \\
\hline
\end{tabular}


Hizkuntza trebetasunekin lotu daitezkeen hizkuntza-teknologiak helduen euskalduntzean ekar ditzaketen onurak aipatuko ditugu:

- Irakurmenarekin lotu daitekeen teknologia erabilgarria izan daiteke, esaterako, AHOTTS eta gisako tresnek testua ahots bihurtzen dutenez, ikasgaiak edota testuak edozein lekutan entzun daitezke irakurri beharrean edo irakurri eta entzun daitezke, baita norbere ahotsarekin ere (sintetizatzen bada norberaren ahotsa). Esaterako, ElhuyarTTS tresnarekin Berria egunkaria entzun dezakete ikusteko arazoak dituztenek. Edo zientzia.eus aldizkaria entzun daiteke eta irakurri ahala testua nabarmendu eta berarekin mugitzen da, erabiltzaileak erritmoa, generoa edota bestelako gauzak erabaki ditzakeelarik. Horrez gain, HIZEBA test egokitua aipatu nahi dugu. Test horretan zenbat eta hobeto ulertu irakurritakoa, orduan eta galdera zailagoak egiten ditu, norberaren ulermen maila zehaztu arte. Bukatzeko, e-liburutegia aipatu nahi dugu, irakurtzeko, entzuteko eta liburuak markatzeko hainbat modu dakartzalako.

- Mintzamena lantzeko teknologiak ere zenbait abantaila ekar ditzake. Esaterako, Mintzanetek euskararekin kontaktuan ez dauden pertsonei euskara praktikatzen lagunduko die eta autoikaskuntza eta mintzapraktikekin euskara ikasi dutenen adibide esanguratsuak badaude (ez bakarrik euskara ikasteko, baizik eta euskararen bariazioak ere ikasteko). Horrez gain, bideokonferentziek zenbait abantaila dute, txataren erabilera-akatsak nabarmentzeko eta gero zuzentzeko, baina komunikazioa eten gabe (Iturricastillo, 2015). Horrez gain, PRAAT (Boersma, 2002) eta antzeko tresnak oso baliagarriak izan daitezke, modu grafikoan ikasleari prosodiari buruzko azalpenak emateko edota ikaslearen jardun laburrak aztertzeko. Aipagarria da ADITU ahotsa automatikoki transkribatzen duen sistema audio- eta bideo-fitxategietatik; horrez gain, transkribapena zuzentzeko eta bideoetan azpidatziak txertatzeko ingurunea ere oso baliagarria da.

- Entzumena lantzeko eta komunikazio-gaitasuna material multimodalekin lantzeko Ikuslang eta antzeko tresnak edo ANT Video webgunea ${ }^{10}$ oso erabilgarriak izan daitezke. Bideoekin lan egiteak, besteak beste, material errealekin eta berrerabilgarriekin lan egitea dakar, eta horrek hizkuntzen irakaskuntzari dakarkion abantaila handia da. Bestalde, ReadLang tresna ere oso interesgarria da hezkuntza- eta hizkuntza-teknologiak txertatuz, programa euskara ikasteko oso egokia baita; izan ere, guk aukeratutako hizkuntza batetik euskarara itzul daitezke hitzak (klik bat eginez) edota alderantziz, euskaratik beste hizkuntza batera egin genezake, itzulpen automatikoa

${ }^{10}$ Ikusi bideo honetan ANT Video erabilita komunikazio-gaitasuna lantzeko bideoan jarritako markak: https://ant.umn.edu/etivestoxc/view. 
erabiliz. Baliabide horrek bideoekin eta azpidatziekin ere lan egiten uzten du eta egindako interakzio guztiak gorde eta erabiltzaileak nahi duenean memoria-jokoen bidez errepasatzen du, egindako kontsulta guztiak eta lexikoa zein egiturak ikasteko baliagarria da.

Eskolan hizkuntza-baliabide errealak eta multimodalak erabiltzen hasten garenean, zaila izaten da corpus horren gainean bilaketak egitea, gai jakin bat edota egitura bat lantzeko edo motibatzeko bideoa bilatzeak denbora handia eskatzen du, bideoa ikusi behar bada. Arazo hori saihesteko eta elkarrizketa errealetan materiala bilatzeko proiektu hau aipatu nahi dugu: http:/www.coerll.utexas.edu/spintx/ video/349. Proiektu horretan, behin transkribapena eginda, bilaketak egiteko hizkuntza-teknologia erabili da hitzak, aditz erroak, kategoriak eta abar identifikatzeko. Horrez gain, bideo bakoitzean bilaketak egin ahal izateko bestelako informazioa ere gehitu zaio eskuz. Horrela, behin norbaitek eskuzko lan hori eginda, beste edonork erabil dezake material errealean bilaketa egiteko aukera. ${ }^{11}$

- Idazmenarekin loturiko tresna asko daude, eta oso interesgarriak (batzuk beste zenbait trebetasun ere lantzeko erabil daitezkeen arren). Esaterako, idazteko online sistemei dagokionez, ikaslearentzat momentuko feedbacka izaten da garrantzitsuena eta gehien ikasten duen unea da. Sarri askotan irakasleak bere zuzenketak aste bat edota pare bat egun geroago ematen dizkio ikasleari eta hark zuzenketari ezin dio behar besteko garrantzirik eman, zuzenketa unean akats horien zuzenketa birproduzitzeko beharrik ez duelako. Sistema automatikoak, ordea, oso lagungarriak dira autoikaskuntzan ikasleari feedbacka produzitzeko beharra duenean ematen diotelako eta ikasleak produkzio-unean informazio linguistikoko erabaki ezberdinekin elkarreragiten duelako. Ingeleserako, Grammarly ${ }^{12} \mathrm{da}$ online idazten laguntzeko baliabide ezagunetako bat eta online zerbitzu horretan ikasleak testuko akatsak non dituen ikus dezake, eta horiek zuzentzeko iradokizunak ere ikusten ditu; azkenean, zuzenketa norberak egiteko. Ikasleak sistema horrekin asko ikasten du, hasteko, errorea non dagoen produkzio-unean esaten zaiolako, ondoren alternatiba ezberdinak proposatu eta egokiena aukeratu behar duelako. Gaztelaniaz ere badago Artext ${ }^{13}$ sistema (testu espezializatuetako corpusetatik lortutako informazioa erabiltzen du ikaslearen

11 Dagoeneko, beste hizkuntza batzuetan, ingelesean, esaterako, bideoak modu automatikoan transkribatzen dira (ikusi youtuben azpititulu automatikoaren aukera). Behin bideo horiei transkribapena eginda, esandako testuari informazio linguistikoa erants dakioke automatikoki, material erreala eta multimodala klasean erabiltzeko.

12 https://www.grammarly.com/.

13 http://sistema-artext.com/. 
testua aztertu eta aholkuak emateko) eta euskaraz IDAZLAGUN ${ }^{14}$ sistema dago, euskaraz idaztean formazko edo axaleko hizkuntzazalantzak argitzeko tresna (bertan aldez aurretik idatzitako deskribapen linguistikoak kontsultatu daitezke).

Sistema automatikoez gain, oso interesgarriak izan daitezke eskuz testuak zuzentzeko baliabideak. Esaterako, MARKIN tresna oso baliagarria da ikasleari edota ikaskideari feedbacka bere testuaren gainean emateko. Metodo hau zuzentzeko bestelako metodoak (testu editoreetako aldaketa kontrola) baino interesgarriagoa da, batetik, akats-motak aldez aurretik diseinatu daitezkeelako nahieran (horrek denbora asko aurrezten dio irakasleari eta azalpenak ez ditu behin eta berriro idatzi behar, nahikoa da testuaren gainean klik bat egitea, programak automatikoki azalpen guztia eta puntuazioa jartzeko) eta, bestetik, sistema horrek gainera akats-motak kontatu eta estatistikak ematen dituelako. Horrela, irakasleak edota ikasleek eurek eskolako akats nagusiak eta gehien errepikatzen direnak zein diren ikus ditzakete, eta baita ere norberak egiten dituen akatsak ohikoak diren (taldekoak) edota norberarenak soilik. Tresna hau oso baliagarria da irakasleentzat, zuzenketak ikusteko ikasleak sareko nabigatzailea soilik behar duelako (Internet konexiorik gabe ere badabilena). Idazketa digitalak, irakasleari denbora aurrezteaz gain, zuzenketak eta testuak lantzeko aukera berriak ekar diezazkioke, esaterako, ko-ebaluazioa eta hetero-ebaluazioa egiteko tresna interesgarria delako (zuzenketa baten gainean beste zuzenketa bat egin daitekeelako).

Hizkuntza-teknologiak ekarri duen aldaketarik nabarmenena datuekin lan egiteko ohitura da. Izan ere, hizkuntza-teknologian datuak eraikitzeko joera nagusia corpusak egitea da (erreferentziazko corpusa eta ikasle-corpusak) eta corpus horiek kontsultatzeko, aztertzeko edo bistaratzeko garatu dira teknologia-tresnak.

- Corpusak dira ordenagailu batek irakurri eta ezaugarri bat duten testu-multzo digitalak. Corpusak argitaratzen direnean, bilaketa tresna eta hizkuntza-datuak erabiltzaileak nahi dituen eran erakusteko programak dituzte. Oro har, testu-multzo handiak direnean, hizkuntza-ezaugarri askoren artean aukera daiteke, baina zaila izaten da norberak testu-multzo berriak bertara igotzea. Adibidetzat hemen corpus esanguratsu batzuk:

- Lexikoaren Behatokia, ZT corpusa, UPV/EHUkoak eta Ixa Taldekoak.

- Norberaren corpusak: corpus handiak kontsultarako eta zenbait ikerketa egiteko baliagarriak badira ere, eskolan sortzen diren testu-mul-

${ }^{14}$ http://idazlagun.elhuyar.eus/tresna/default.aspx. 
tzoak aztertzeko tresnak ere garatu dituzte ikertzaileek, esaterako, Anthonyk (2004) ANTCONC garatu zuen, edota CLARIN eta antzeko ikerketa-azpiegiturek, honako hauek:

- Voyant Tools (Sinclair eta Rockwell, 2016) hizkuntza-datuak (karaktereetan eta hitzetan oinarritutakoak) bisualizatzeko tresnamultzo handiak elkarlotzen dituen web-zerbitzua da. Tresna letretan oinarritzen den edozein hizkuntzatarako baliagarria bada ere, bere muga hor du eta, esaterako, euskarazko informazio linguistikoa ez du kontuan hartzen eta ezin da informazio morfologikoa edo linguistikoa kontuan hartu, esaterako, kategoriak, morfemak edota lemak. Arestian nabarmendu dugun bezala, zenbait hizkuntzatan eta atazatan garrantzitsua da informazioa morfologikoa kontuan izatea.

- ANALHITZA (Otegi et al., 2017) norberaren testuetako datuak ateratzeko analizatzaile lexikal orokorra da hiru hizkuntzetarako: euskara, ingelesa eta gaztelania. Beraz, hizkuntza horiek soilik aztertzen ditu eta informazio linguistikoa erabiltzen da hizkuntzaren askotariko azterketak egiteko. Tresna erabilerraza da eta ez da informazio teknikorik jakin behar. Tresna honen muga nagusia da datuak bistaratzeko kalkulu-orrietan dauden tresnetara mugatzen dela.

Hizkuntzaren alderdi formalari dagokionez, tresna asko sortu dira corpusak aztertzeko eta datuak bistaratzeko.

- Teknologiak ahalbideratu du hiztegi guztiak plugin batean izatea (Euskalbar) edota hiztegien katalogo osatua izatea (hiztegiak.net), eta gramatika aholkuak biltzea: EHULKU, Sareko Euskal Gramatika, Euskaltzaindiaren gramatika lantegiak, besteak beste.

- Hizkuntza-teknologiari dagokionez, corpusetatik informazioa ateratzeko hainbat baliabide sortu dira: EDBL, esaterako, euskarazko datu-base lexikala, euskarazko unitateak eta beraien arteko erlazioak zein diren jakiteko. Morfeus analizatzaile morfologikoa eta MALTIXA analizatzaile sintaktikoa, edota euskarazko zuhaitz sintaktikoak manipulatzeko baliabideak: zuhaitz-bankuak eta Arborator, zuhaitz sintaktikoak bistaratzeko web-zerbitzua.

- Horrez gain, hizkuntza-teknologian oinarrituta, webgune interesgarriak sortu dira ikasleek hizkuntzak beste modu batzuetara ikasteko; esaterako, ikuspegi lexikalean oinarrituta dagoen Lextutor webgunea (hainbat hizkuntza dituen arren, ez du euskara) baliabideak sortzeko eta lexikoa zein gramatika maiztasun handiena duten egituretatik ikasteko.

Aipatutakoez gain, espreski euskararako sortu diren hiru proiektu aipatuko ditugu laburki, nolabait euskaraz hizkuntza-teknologiak erabilita zer 
egiten ari den erakusteko eta CLARINen laguntzarekin elkarlanean egin daitezkeen tresna eta proiektu berriak diseinatzeko eta lantzeko.

Lehenengoa, idatzizko trebetasunari dagokionez, ikas-materialgintzan ari direnekin hitz eginda konturatu gara eskoletan gero eta gutxiago lantzen direla testuen laburpen idatziak, eta gero eta gehiago egiten direla irudi bidezko laburpenak edota buru-mapak. Hori gerta daiteke, alde batetik, edukiaren antolamendu grafikoak gero eta garrantzi handiagoa duelako ikaskuntzan; baina, beste alde batetik, irakasleek gero eta denbora gutxiago dutelako ikasleen lanak zuzentzeko. Hori horrela, ulermen ariketak konprobatzeko idatzizko narrazio edota laburpenak garatzeko estrategiek denbora gutxiago dute eskolan. Teknologiarekin hor laguntzeko asmoarekin laburpenen sailkapen automatikoa egiteko sistema bat (Atutxa et al., 2017) lantzen hasi da Ixa Taldea, Ikastolen Elkartearekin lankidetzan. Horretarako, Compress-eus ${ }^{15}$ tresna sortu da: ikasleek tresna horretan egiten dutena biltzeko, ikasleen laburpen corpusak biltzeko eta laburpenak automatikoki ebaluatzeko. ${ }^{16}$

Bigarrena, euskaraz, galdera-erantzun automatikoak sortzeko SENEKO ${ }^{17}$ sistema garatu zuen Lopez-Gazpiok (2013). Sistema horrek aukera ematen dio irakasleari galderak eta erantzunak sortzeko eta horien erantzunak jasotzeko, baina, irakasleak egindako galderez gain, bestelako galderak eta haien erantzunak nahiz distraktoreak modu automatikoan ere sortzeko ingurune digitala da. Kasu honetan, euskaltegien lankidetzarekin, informazio morfosintaktikoan oinarrituta galderak eta distraktore automatikoak sortzen dira. Etorkizunean, hizkuntza-teknologian oinarriturik diskurtso-informazioa edota bestelako informazio konplexuagoa erabil liteke bestelako galderak egiteko.

Hirugarrena, Basque in the Making: A Historical Look at a Language Isolate (BIM) ikerketa-proiektua ere aipatu nahi dugu. BIMen helburu nagusia da euskararen gramatikaren azterketa diakroniko sistematikoa egitea. Testu historikoen (XV. eta XVIII. mende bitarteko euskara ez-estandarreko testuekin) corpusa osatu ondoren (faksimileak lortu, hizkuntza-teknologiarekin testuak transkribatu, normalizatu eta testuak analizatu), datu-basea eraikitzen da, bilaketa sistematiko konplexuak egiteko. Esaterako, egun Testu Historikoak ${ }^{18}$ (Belamendia, 2016) webgunean «gutxi» lema bilatuta, Axularrek erabili zuen «guti» hitza erabiltzen dituen bost esaldiak bilatzen ditu eta, horietako batean klik eginda, faksimilean agertzen den orria ikus dezakegu. Sarritan euskara ikasten duten ikasleak aipatzen ditugunean, hasierako mailako ikasleak izaten ditugu buruan; bada, mota honetako ikerketak garatuz gero, ikasle aurreratuentzat ere baliagarriak izan daitezkeen

15 http://ixa2.si.ehu.es/clarink/tresnak/compress-eus/.

16 Bertso-eskola digitalak ere hizkuntza-teknologia erabiltzen du bertsoen silabak eta errimak bilatzeko: http://www.bertso-eskolak.eus/web/arbeldigitala.

$17 \mathrm{http}: / /$ ixa2.si.ehu.es/seneko/.

18 http://ixa2.si.ehu.es/testuhistorikoak/s/lemma/gutxi. 
proiektuak sor daitezke, edota ikasle horiek errazago irakur ditzakete testu historikoak (euskara batuan) eta tradiziozko literaturan dagoen aldakortasunaz jabetu daitezke (faksimileari begiratuz).

Bukatzeko, eskoletan proiektu digitalak lantzeko teknologia ere oso erabilgarria izan daiteke (ikusi https://digitalhumanities.berkeley.edu/resources). Bertan, bilaketak hainbat modutara egin daitezke; bi aipatzearren: i) helburu jakin baterako tresnak erabili nahi badira eta ii) datu-mota batekin lan egin nahi bada.

\section{ARAZOAK, ERRONKAK ETA AUKERAK}

Esanak esan, asko dira euskaltegiek aurrez aurre dituzten arazoak eta erronkak, baina baita aukerak ere. Ikus ditzagun zertan diren horietako batzuk.

\subsection{Arazoak}

Artikulu honen 2.1 atalean adierazi bezala, gaur egun indarrean dauden curriculum-diseinuak egungo errealitatera egokitu gabeak dira, eta, horregatik, premiazkoa da horien berrikusketa eta egokitzapena.

Gainetik baino ez bada ere, hainbat tresna, aplikazio eta teknologia aurkeztu ditugu, irakasleek askotan uholde gisa har ditzaketenak, zalantzarik gabe. Ildo horretatik, Roman-Mendozak (2018) baieztatzen duen moduan, teknologiaren garapen ikaragarri azkarrak irakasleen artean ezinegona eta kezka sortzen ditu. Berrikuntzak eta aurrerapenak ugariak dira; aplikazioak eta tresna berriak etengabe sortu eta plazaratzen dira; eta irakasleek berrikuntzaren aurrean pairatzen duten estresa gero eta handiagoa da. Irakasleen itomen-sentipena, beraz, erreala eta ulertzekoa da.

Bestalde, arazo larria ere bada sarritan euskarri berrietan praktika zaharkituak aurkezten zaizkigula. Zer-nolako balioa dute, adibidez, ulertu beharrik izan gabe ere, etengabeko errepikapenean oinarritzen diren ikas-jarduerek? Horien diseinuan erabilitako aplikazioa gorabehera, enfasia hizkuntza-erabileran eta ikas-prozesuan jarri ezean, ikuspuntu metodologikotik bederen zeharo gaindituta dauden hezkuntza-praktikak ugaldu eta indarberritu daitezke.

Hizkuntza-teknologiez ari garela, oso garrantzitsua izango da Europan garatu diren CLARIN eta antzeko hizkuntza-azpiegiturak euskararako garatzea. Azpiegitura horrek, batetik, hizkuntza-teknologia garatzaileak eta hizkuntzateknologia behar dutenak harremanetan jarriko lituzke elkarlanean baliabide estrategikoak garatzeko eta, bestetik, sortu den hizkuntza-teknologia guztia webgune bakarretik eskuragarri jarri, teknologia mantendu eta teknologia erabiltzeko aholkularitza eskaini beharko luke.

Horrela, zaila da egun teknologia horiek guztiak Helduen Euskalduntzean txertatzea eta, gainera, teknologia horren guztiaren gogoeta pedago- 
giko sendoa egin beharko litzateke, nork bere testuingurura egokitzeko aukera errealak izateko eta ikas-prozesuari benetan zertan laguntzen dioten aztertzeko. Une honetan, ikuspuntu kritikorik eza da arazo larrienetako bat, ezbairik gabe.

Azkenik, sarritan sumatu izan dugu euskaltegietan, baita bestelako hezkuntza-zentroetan ere, behar eta premia errealen analisi falta, datu errealetan oinarritzeko metodoen, ikerketen edota ikerketa-azpiegituren gabezia dela-eta. Horrela, ohikoa izaten da berrikuntzari esker lortu nahi den eta, beraz, helburu dugun azken egoera hori irudikatzeko ezintasuna. Behar bezala atzeman gabeko premiei erantzun nahi dien ustezko berrikuntza-prozesu batek nekez diseina ditzake zehaztu gabeko azken egoerara ailegatu ahal izateko lan-estrategiak eta prozedurak.

\subsection{Erronkak}

Artikulu honen 2.2 atalean aipatu bezala, Helduen Euskalduntzean era askotako erabilerak eta esperientziak bultzatu dira azken urteotan, baina, horiek gorabehera, ez dirudi Helduen Euskalduntzean behar besteko hausnarketarik eta gogoetarik egin dugunik ikaskuntza formalean teknologiak izan behar duen egitekoaz. Are gehiago, urrun samar gaude jendartean horren ohikoak diren tresnen eta aplikazioen erabilera-tasatik: ikasle eta irakasle gehienek inguru digitalean gero eta jardun esanguratsu gehiago egiten dute (nolabait bizimodua aldatzen ari direnak), baina eskolan eta euskaltegian ikasle eta irakasle gehienek ez dituzte ikasteko eta ikertzeko baliabide digitalak modu esanguratsuan erabiltzen. Muruak (2016) iradokitakoaren ildotik, gaitasun digitalaren garapenak ikuspegi pertsonala badu ere, «erakundearen ikuspegia balioetsi eta landu behar da».

Ildo beretik, Europar Batasunaren 2018/2028 (INI) ebazpenak (Hizkuntza Berdintasuna Aro Digitalean - On Language Equality in the Digital Age) bere burua behartzen du Europako hizkuntza guztientzat hizkuntzateknologiak garatzeko finantziazioa ematera, arlo horretan dauden eskariak eta beharrak asetzeko asmoz. Euskarari dagokionez, hizkuntza-teknologia garatzeko ikerketa-azpiegiturek Euskal Herriko hainbat euskaltegi, erakunde eta irakaslerekin lankidetzan honako hauek garatu beharko lituzkete, gure ustez:

- Datuetan oinarrituko diren ikerketek honako galdera hauei erantzun beharko liekete: Nola lagun dezake hizkuntza-teknologiak eskolan? Non lagunduko luke hizkuntza-teknologiak eta analisi automatikoak hizkuntzaren i(ra)kaskuntzan? Tarteko hizkuntza prozesatzeko eta ikasleei feedback automatikoak emateko zer behar dugu? Zein dira egun premiazko proiektuak eskolan ikerketako hizkuntza-azpiegiturek laguntzeko? 
- Galdera horiei erantzun ahal izateko, pedagogian eta hizkuntza-teknologian arituek proposatu beharko lituzkete elkarlanean euskara ikasteko MOOCak edo Online Ikastaro Ireki Masiboak, hizkuntza-baliabideak (material erreala edo corpus multimodalak hizkuntza-teknologiarekin aberastua) ${ }^{19}$ eta horiek eskolan aplikatzeko modu egokiak.

- Horrez gain, aro digitalak dakartzan erronkak eta aukerak egoki baliatzeko behar-beharrezkoa da irakasleen prestakuntza multidiziplinarra: didaktikan, pedagogian, hizkuntzalaritzan, informatikan eta psikologian.

- Orobat, euskaltegietan hizkuntza-teknologia arrakastatsua izateko, zalantzarik gabe, ahozko teknologiaren garapena izango da gakoa. Esaterako, ikaslearen jarduna automatikoki transkribatzea: ahotsetik testura, testua automatikoki analizatzeko eta feedback automatikoa edota irakasleari feedbacka emateko laguntza tresnak garatzea (www.aditu.eus tresna, esaterako) eta horien erabilera bultzatzea. Edo, bestela, chatbotak, ikasleak ordenagailuaren galderei bat-batean erantzuteko eta ordenagailuak feedbacka emateko. Bestalde, ondo legoke zenbait euskaltegitan garatu diren sistemak, esaterako, ikasle bakoitzaren erritmora egokitzen diren sistemak, hala nola DDK System, Bai\&by-rena edo Feedbook (Rudzewitz et al., 2020), irakasle guztion eskura egotea, testu zehatzak irakurtzeko ikaslearen ahozko jarduna kudeatzeko tresnak, esaterako, eredu bat entzun eta hori imitatuz ikasleak berea grabatzeko. Horrela, modu automatikoan komunikazio estrategiak konparatu eta ebaluatzeko: intonazio, bolumen, geldiune eta erritmo aldaketak kontuan hartuz.

\subsection{Aukerak}

Hezkuntza- eta hizkuntza-teknologiek era askotako aukerak eskaintzen badizkigute ere, hemen, bereziki, ikaskuntza informala bultzatzekoak azpimarratu izan ditugu. Izan ere, euskalduntzeak bizialdi osoan zeharreko ikas -prozesuari esker izango da posible. Zalantzarik gabe, euskaltegia, eskola, unibertsitatea edo antzeko ingurune formalen garrantzia oso handia da, baina horiek ezin dute ikas-prozesuaren arrakasta ziurtatu, ingurune informaletako ikaskuntzarekin lotu ezean.

Horren ildotik, argigarria da HEOCek euskalduntzearen maila bakoitzari esleitzen dion ordu-kopurua (2. irudia) zehaztean erabiltzen dituen irizpideak. Alde batetik, hezkuntza formalari dagozkion irakastorduak eta, bestetik, ikaskuntza ez-formalari nahiz informalari dagozkionak (bakarlana

19 Adibidez, corpus to classroom: https://sites.la.utexas.edu/corpus-to-classroom/. 
eta erabilera askea). Gure ustez, teknologiek aukera ezin hobea eskain dezakete erabilera aske eta autonomo horretan.

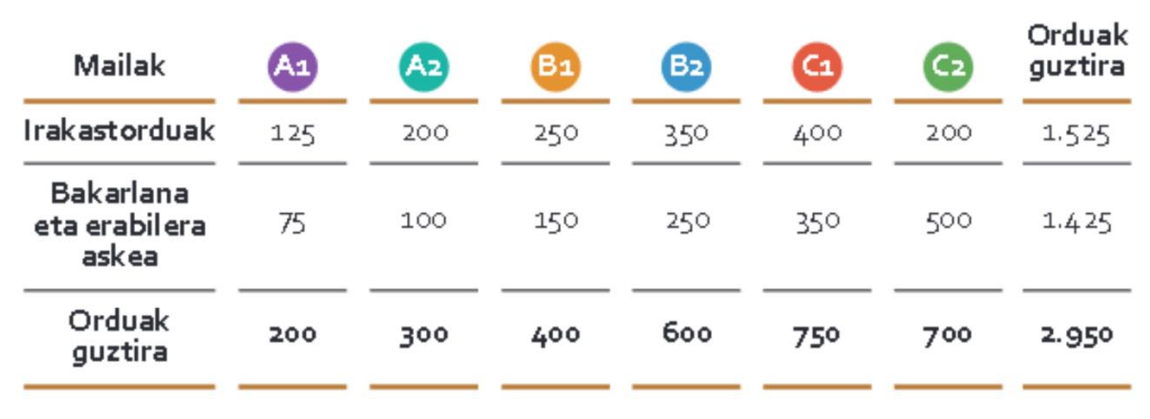

Iturria: HABE (2015)

\section{2. irudia \\ Euskalduntzearen mailak}

Hizkuntza-teknologiaren askotariko erabilerak egin daitezke, ikaslearen eskolaz kanpoko (bakarlana eta erabilera askea) orduen arabera. Hasierako mailetan irakasleak materialak prestatzeko eta ikasleak etxean egiten dutena errepasatzeko erabil dezake hizkuntza-teknologia. Ikasleak hizkuntza-teknologia ezagutu ahala, bakarlanean (teknologiak lagundurik) denbora gehiago pasa dezake eta behar duen ebaluazioa automatikoki jaso dezake. Horrela, irakasleek, ikasle bakoitzaren jarraipena egiteko txostenez gain, eskola orduetan ez lukete akats errepikakorretan eta ikasleak berak zuzen ditzakeen kontuetan aritu beharrik, baizik eta maila goreneko kontuak irakasten: estiloa, ahotsa, erritmoa edo arnasa, argudiaketa diskurtsiboa, zehaztasun lexikoa, besteak beste. Hori horrela, euskara ikasteko proposamen hau arrakastatsua izango bada, edo arrakastatsua den jakiteko, nolabait eskolan ikasleak egindako bakarlanaren ebaluazioa egin behar da. Hori egin ahal izateko, behar beharrezkoa da garatzea hezkuntza-teknologiak eta hizkuntza-teknologia egokiak izatea eta ikuspegi teknopedagogiko sendoa eta ebaluagarria.

\section{BIBLIOGRAFIA}

AEK (1986). Jokabide Nozio-Funtzionala. URRASPIDE 13, Donostia: AEK.

Aldezabal, I.; Arriola, J. M.; Diaz de Ilarraza, A.; Sarasola, K. (2005). Hizkuntzalaritza konputazionala. Bilbo: UEU.

Anthony, L. (2004). AntConc: A learner and classroom friendly, multi-platform corpus analysis toolkit. Proceedings of IWLeL, 7-13. 
Abel Camacho, Mikel Iruskieta

Atutxa, U. Iruskieta, M. Ansa, O. Molina, A. (2017). COMPRESS-EUS: I(ra)kasleen laburpenak lortzeko tresna. In EUDIA: Euskararen bariazioa eta bariazioaren irakaskuntza-III (87-98).

Arroyo-Sagasta, A., Pereira, J. (2019). Online eta Blended Learning: Komunikazio digitala, LMSak eta tresnak. In IKTak eta konpetentzia digitalak hezkuntzan. Eds: Iruskieta, M. Maritxalar, M. Arroyo-Sagasta, A. Camacho, A. 179-191. UEU eta UPV/EHU. Bilbo.

Arroyo-Sagasta, A. (2019). Tresna digitalen sailkapena konpetentzia digitalaren eremuen arabera [Bideo-fitxategia]. Hemendik berreskuratua: https://labur. eus/fuiv4

Arteach, E. (2016). Web 2.0 arora egokitu beharra, hizkuntzaren mesedetan: esaera zaharrak eta euskal kultura Instagramen bitartez. e-Hizpide, 88 .

Aldazabal, J., Fernandez, M., Zaballa, I. (2015). WhatsAppa, lagun-taldetik haratago. Hizpide, 85, 46-65.

Bel, N.; Gonzalez-Blanco, E.; Iruskieta, M. (2016). CLARIN Centro-K-español. Procesamiento del Lenguaje Natural, 57, 151-154.

Belamendia, J.A. (2016). Testu historikoak kontsultatzeko plataforma. UPV/EHUko Informatika Ingeniaritzako Gradu Amaierako Lana. Interneten eskuragarri: https:// addi.ehu.es/bitstream/handle/10810/19423/Memoria_JonAnderBelamendia. pdf? sequence $=1$.

Boersma, P. (2002). Praat, a system for doing phonetics by computer. Glot international, 5 .

Breen, M. P. (1987). Contemporary paradigms in syllabus desing (I-II). In Language teaching, 20-2\&3. (Espainieraz: «Paradigmas contemporáneos en el diseño de programas de lenguas» (I) eta (II). Signos. Teoría y práctica de la educación, 19 -20, 1996-1997, 50-64 / 52-73.

Camacho, A. (2004): Proyecto de materiales en un contexto de autoaprendizaje: hacia un hipertexto. In IX Trobada de Centres d'Autoaprenentatge. Barcelona: Generalitat de Catalunya.

Camacho, A. (2019): e-learningaren iragana, oraina eta geroa: ohar batzuk. In Iruskieta, M. et al. (arg) IKTak eta konpetentzia digitalak hezkuntzan. UEU \& UPV/EHU: Bilbo.

Camacho, A.; Lonbide, P. (2016): Zer dugu Moodle-ren kontra? Eta alde? e-Hizpide, 89.

Dorronsoro, M. (2014). HABEren IKASBIL atariaren erabilera: datuak, iritziak eta analisia. Hizpide, 82, 67-89.

EJ. (2016). Euskarazko IKTak Gomendioak herri-aginteentzat. Interneten eskuragarri: https://labur.eus/xw2Hb.

Europako Kontseilua (2018). Common European Framework of Referencefor Languages: Learning, teaching, assessment. Companion volumen with new descriptors. [Hemendik berreskuratua: https://labur.eus/syrZL]

Europako Kontseilua (2001). Common European Framework of Referencefor Languages: Learning, teaching, assessment. Cambridge: Cambridge University Press.

Guillén, N., Aizpitarte, A. (2015). Euskara-irakasleak badu nortasun... digitalik? Hizpide, 85, 66-78.

HABE (2015). Helduen Euskalduntzearen Oinarrizko Curriculuma. Donostia: HABE. HABE (1999). Helduen Euskalduntzearen Oinarrizko Kurrikulua. Donostia: HABE. HABE (1989). Alfabetatzeko eta Euskalduntzeko Programak. Donostia: HABE. 
HABE (1983). Helduen euskalduntzea programatzen - 84. Donostia: HABE.

Hernáez I., Navas E., Odriozola I., Sarasola K., Díaz de Ilarraza A., Leturia I., Díaz de Lezana A., Oihartzabal B. eta Salaberria J. (2012). Euskara aro digitalean. Interneten eskuragarri: http://www.meta-net.eu/whitepapers/e-book/basque.pdf

Hinrichs, E.; Krauwer, S. (2014). The CLARIN Research Infrastructure: Resources and Tools for E-Humanities Scholars. In Proceedings of the Ninth International Conference on Language Resources and Evaluation (LREC-2014), May 2014, 1525-1531.

Iruskieta, M.; Otegi, A.; Uria, L.; Diaz de Ilarraza, A.; Artolazabal, A. (2019). Zer i(ra)kas dezakegu geure corpusekin «jolastuz»? In Traineru bete lagun: Iñaki Gaminde omenduz (35-66). Bilbo: UPV/EHU.

Iturricastillo, A. (2015). IKTen bidezko komunikazio sinkronoa euskara-ikasleekin. Hizpide, 85, 74-80.

McNamara, D. S., Allen, L. K., Crossley, S. A., Dascalu, M., \& Perret, C. A. (2017). Natural language processing and learning analytics. Handbook of learning analytics, 93.

Lewis, M. (1993). The lexical approach. Hove: Language Teaching Publications.

Lewis, M., Gough, C., Martínez, R., Powell, M., Marks, J., Woolard, G. C., \& Ribisch, K. H. (1997). Implementing the lexical approach: Putting theory into practice. Hove: Language Teaching Publications. Vol. 3, No. 1, pp. 223-232.

Lopetegi, E. (2015b). «Jon eta Jone» irratsaioaren lanketa didaktikoa IKASBIL atarian. Hizpide, 87, 89-101.

Lopetegi, E. (2015a). Bagoaz!, A1 eta A2 mailetarako ikasmaterialak IKASBIL atarian. Hizpide, 86, 81-91.

Lopez de Lacalle, O. (2019). Bistaratze-teknikak konpetentzia digitaletan. In Iruskieta, M. et al. (arg) IKTak eta konpetentzia digitalak hezkuntzan (345-358). UEU \& UPV/EHU: Bilbo.

López Gazpio, I. (2013). Seneko: galderak automatikoki sortuz testuak lantzeko aukera ematen duen aplikazioa.

Luque, M.LL. (2004). Adquisición-aprendizaje del Euskara a través de la inmersión total precoz (2-4 años): Análisis psico-socio-lingüístico-pedagógico. Doktorego tesia. UPV/EHU.

Nafarroako Gobernua (2011). Helduak Euskalduntzeko Nafarroako Curriculuma (HENAC). [Hemendik berreskuratua: http://www.navarra.es/home_eu/Actualidad/BON/Boletines/2011/124/Anuncio-0/]

Murua, I. (2016). Euskaltegi eta autoikaskuntza-zentroetako irakasleen gaitasun digitalak, IKANOS proiektuaren ikuspegitik. e-Hizpide, 89.

Murua, M., Txabarri, L. M. (2016). Irakasbil, HABEren atari berria. e-Hizpide 88.

Otegi, A.; Imaz, O.; Dı́az de Ilarraza, A.; Iruskieta, M.; Uria, L. (2017). ANALHITZA: a tool to extract linguistic information from large corpora in Humanities research. Procesamiento del Lenguaje Natural, 58, 77-84.

Perales, J. P. (2000). Euskara-ikasle helduen ikas-prozesua: ikaslearen baitako zenbait aldagairen eta arrakastaren arteko erlazioa. Bilbo: UPV/EHU.

Román-Mendoza, E. (2018). Aprender a aprender en la era digital: tecnopedagogía crítica para la enseñanza del español LE/L2. Routledge.

Rudzewitz, B. Ziai, R. Nuxoll, F. De Kuthy, K. Meurers, D. (2020). Enhancing a Web-based Language Tutoring System with Learning Analytics. Joint Proceedings of the Workshops of the 12th International Conference on Educational 
Abel Camacho, Mikel Iruskieta

Data Mining co-located with the 12th International Conference on Educational Data Mining (EDM 2019). CEUR Workshop Proceedings, 2592, 1-7.

Saenz de Biteri, I. (2009). Euskararen irakaskuntza eta blogosfera. Bat: Soziolinguistika aldizkaria, 72, 99-109.

Sagarzazu, I. (2019). Ordenagailu bidezko hizkuntzaegiaztatzegintza. e-Hizpide, 94.

Sinclair, S., \& Rockwell, G. (2016). Voyant tools. Interneten eskuragarri: http:// voyant-tools. org/ [Irailak 5, 2016].

Soto, R. (2015). Apuntes sobre la adquisición de la morfosintaxis del euskera en niños de 2 y medio a 5 años. Revista de Logopedia, Foniatría y Audiología, 35, 30-49.

Tolosa, A. (2019): Hizkuntzak ingurune digitalean ikasten eta irakasten: praktikaren eskutik AEKn. In Iruskieta, M. et al. (arg) IKTak eta konpetentzia digitalak hezkuntzan (255-261). UEU \& UPV/EHU: Bilbo.

Trujillo, F., Salvadores, C. eta Gabarrón, Á. (2019). Tecnología para la enseñanza y el aprendizaje de lenguas extranjeras: revisión de la literatura. RIED. Revista Iberoamericana de Educación a Distancia, 22(1), 153-169. doi: https://doi. org/10.5944/ried.22.1.22257

Urain, T. (2010). Talde mistoetan foroak erabiltzeko zenbait iradokizun. Hizpide, 74, 63-82.

Warschauer, M., \& Meskill, C. (2000). Technology and second language learning. In J. Rosenthal (Ed.), Handbook of undergraduate second language education (303-318). Mahwah, New Jersey: Lawrence Erlbaum [Hemendik berreskuratua: http://education.uci.edu/markw-tslt.html]

Wilkins, D. A. (1976). Notional syllabuses: A taxonomy and its relevance to foreign language curriculum development. Oxford Univ Pr.

Zubizarreta, X. (2013). AISA online ikastaroa. Hizpide, 80, 68-78.

\section{WEBGRAFIA}

AEK-ko egela: http://www.egela.aek.eus/

AhoSR: ahotsa testu bihurtzeko: https://aholab.ehu.eus/aholab/ahosr-automaticspeech-recognizer-for-basque/

Aditu.eus: bideoetako ahotsa testu bihurtzeko: https://aditu.eus/

Ahotts: testua ahots bihurtzeko: https://aholab.ehu.es/tts/

ANALHITZA: aztertzaile morfo-lexikalak: http://ixa2.si.ehu.es/clarink/analhitza.php?lang=eu armiarma.eus eta e-liburutegia: liburuak, audio-testuak...: https://armiarma.eus/ eta http://www.eliburutegia.euskadi.eus/

Compress-Eus: laburpenak kudeatzeko eta ebaluatzeko tresna: http://ixa2.si.ehu. es/compress-eus/

Ahozko corpusak: www.ahotsak.eus bariazioa, baina baita eredugarria ere

EDBL: datu-base lexikala: http://ixa2.si.ehu.es/edb1/

EHULKU, SEG, Euskaltzaindia, Gramatika lantegiak: http://www.ehu.eus/ehulku/ orokorra/kontsultagunea.html eta https://www.ehu.eus/seg/

ElhuyarTSS testua ahots bihurtzeko: http://tts.elhuyar.org/

Euskalbar: https://addons.mozilla.org/eu/firefox/addon/euskalbar/, Euskalterm: http://www.euskadi.eus/euskalterm/ eta hiztegiak.net http://www.hiztegia.net/ 
Euskaljakintza / http://euskaljakintza.com/

Grammarly: testuen zuzenketa automatikoa: https://app.grammarly.com/

HIZEBA: test egokitua / http://www.irale.hezkuntza.net/web/guest/hizeba

Hobelex: zuzentzaile ortografikoa: www.uzei.eus/hobelex/

Hot Potatoes: ariketa automatikoak: https://hotpot.uvic.ca/

IDAZLAGUN: idazteko eta zalantzak argitzeko ingurunea: http://idazlagun.elhuyar.eus/tresna/default.aspx

Ikasbil: http://www.ikasbil.eus/web/ikasbil/home

Ikuslang: ahozko testua eta komunikazio-estrategiak lantzeko: https://www.iametza.eus/euskara/ig/ikuslang

Lexikoaren Behatokia: corpusa zalantzak kontsultatzeko: http://lexikoarenbehatokia.euskaltzaindia.eus/

Lextutor: baliabideak sortzeko, ikuspegi lexikaletik: https://www.lextutor.ca

MALTIXA: analizatzaile sintaktikoa: http://ixa2.si.ehu.es/maltixa/index.jsp

MARKIN tool, wikiak, Drive: zuzenketa ingurunean: https://www.cict.co.uk/markin/

Mintzanet: mintzapraktikak: http://mintzanet.net/

Modela: Itzulpen automatikoa: https://www.modela.eus/eu/itzultzailea

Morfeus: analizatzaile morfologikoa: http:/ixa2.si.ehu.es/demo/analisianali.jsp

PRAAT eta WaveSurfer: fonetika aztertzeko: http://www.fon.hum.uva.nl/praat/ eta https://sourceforge.net/projects/wavesurfer/

Santurtziko Udal Euskaltegia: http://ikasgela.santurtzieus.com/

SENEKO: galdera-erantzun sistemak garatzeko ingurunea: http://ixa2.si.ehu.es/seneko/

UD corpusa eta Arborator: euskarazko zuhaitz sintaktikoak manipulatzeko: https:// raw.githubusercontent.com/UniversalDependencies/UD_Basque-BDT/master/ eu_bdt-ud-dev.conllu eta https://arborator.github.io/live.html

Voyant: aztertzaile morfo-lexikalak: https://voyant-tools.org/

WebEx: mintzapraktikak grabatu, txatarekin feedbacka eman: https://www.webex. com/

Xuxen: zuzentzaile ortografikoa: http://xuxen.eus 